\title{
PALACES IN ANDALUSIA AND IRAQ IN THE ISLAMIC ERA: A HISTORICAL COMPARISON PERSPECTIVE
}

\author{
ATHARI IBRAHIM ALSHUAIBI \\ King Faisal University, Saudi Arabia.
}

\begin{abstract}
The purpose of this article is to identify similarities and differences among the characteristics of palaces in Iraq and Andalusia. Historical research design has been used to synthesize data from different sources. In this article, the research has been carried out in five steps: first, formulating the idea and figuring out the research questions; second, designing the research plan and finding the possible resources; third, gathering data from different sources; fourth, analysing collected data to answer the research questions. The researcher tried to look for patterns in the data, especially when comparing the palaces in Andalusia built by Umayyad caliphs with the palaces in Iraq built by Abbasid caliphs. Fifth, outlining the most important findings. The general findings of this research show that although there are huge differences between the palaces in Andalusia and Iraq in terms of design and construction, they still share some aspects such as Islamic decorations. The findings also indicate that the construction style of these palaces was influenced by neighbouring civilizations. Caliphs were keen to build luxurious mansions and so they paid a large amount of money depending on the state's economy.
\end{abstract}

Keywords: Andalusia, caliph, Iraq, Islam, palace.

\section{INTRODUCTION}

Islamic art grew slowly at the beginning due to the fact that Muslims were preoccupied with conquests in order to spread Islam, establish their state, enact laws and develop the country. Poetry was the only art of Muslims at this time. After a period of political stability and as the era of the Umayyad Caliphate (dynasty) began, Umayyad caliphs were keen to develop the arts plus add beauty to their lives, palaces, utensils, etc.

In the beginning, religious factors limited Islamic art only to architecture and ceramics. Islam grew up as an enemy to paganism, which - for them - was in the shape of sculpture, portraits and engravings. Muslims did not want to open the doors for these arts; however, this view soon disappeared when the caliphate regime wanted luxury and extravagance [1].

Because Muslims did not have distinct artistic prowess, they copied art forms and traditions followed in neighbouring countries and civilizations, modifying them to suit their beliefs. Furthermore, they requested artists and artisans [2] in neighbouring countries to help them in their development and urban civilization. It was not long before Islamic arts began to be independent, with its distinct and marvellous ornamentation, which was a brilliant composition of different shapes. The fact that Muslims have copied the art of other nations does not detract it from its intrinsic value [2, p. 240].

Islamic arts reached the height of its prosperity in Andalusia in the 4th century AH. Muslims of Andalusia were the first - of all Muslims - to draw animals, birds and plants to embellish their palaces and utensils. These images later developed to statues and human paintings 
[1, p. 509, 3]. After a certain period, Islamic arts faded, especially in the era of Marabouts and Unitarians whose conservative religious belief led to the prohibition of imagery [1, p. 513].

\section{PALACES IN ANDALUSIA AND IRAQ}

\subsection{Reasons for building palaces}

Through reviewing historical sources, one can find that the most important reason to build palaces was to create a place for relaxation, pleasure and recreation with friends away from the common people [4]. It was assumed that the more the caliph liked the palace, the more he stayed in it [4, p. 136, 5, 6], especially when palaces contained earthly pleasures that were not available in the government houses within cities [7]. Caliphs tended to avoid the bustle of cities, with its exponential population growth [7, p. 111, 8].

Another reason for building palaces was to show off and display wealth and position that the caliph had, whether in Iraq or Andalusia. Every caliph wanted to immortalize his glorious ruling era [7, p. 99].

In Andalusia, there were additional reasons. After Prince Abd Al-Rahman I left the Levant, he had an intense longing for its plants, houses and palaces, and he tried to build palaces in Andalusia similar to the Umayyad palaces in Levant. Also, he planted various trees and palms similar to the ones in Damascus [7, p. 52]. Thus, we can conclude that palaces in general were built for pleasure and luxury away from the general public, as well as to show off, whereas the palaces of Andalusia were built to imitate Arab East palaces, indicating the love for their origins.

\subsection{Naming of palaces}

The names of palaces in Iraq and Andalusia were closely linked with their design, location and the caliphs who built them. For example, 'Al-Gharib' (The Strange) Palace took its name from its strange and unique shape [4, p. 134, 5, p. 238, 6, p. 305, 9]. Also, 'Al-Maleeh' (The Beautiful) Palace was called so because of its beauty and fine construction [6, p. 299, 9, p. 21, 10]. Moreover, there is 'The Bride' Palace, whose name indicates the beauty of its construction and good architecture, as if it were a beautiful and ornamented bride. Caliph al-Mutawakkil has exaggerated its decoration and beauty, and so it has become the most beautiful and the greatest palaces in Samarra [4, p. 134, 6, pp. 294-295, 9, p. 21, 10, p. 197]. Likewise, 'Al-Burj' Palace took its name from its strength and huge building [6, p. 296] (the word Al-Burj means strong fort). Examples also include 'Al-Zaher' (Florid) Palace which was built by Al-Mitamed bin Abbad in Andalusia. Its name comes from the different flowers and trees that surround it [7, p. 113].

There are also palaces that were named after their owners, like Al-Jaafari Al-Muhdith Palace in Iraq, which was built by Caliph Ja'far al-Mutawakkil (the word Al-Muhdith means the new) [6, p. 333]. Similarly, 'Al-Jaafariah' Palace, which was built by Ahmed Ben Hood in Zaragoza, was named after its owner's cognomen 'Abu Jafar' [7, p. 63]. In addition, 'AlZahra', Palace in Andalusia was named after Prince Abdul Rahman Nasser's odalisque, Zahra', with whom he fell in love [7, p. 53].

Besides this, some palaces were named according to their location or region, such as 'Almahozh' Palace which was built in a city called Almahozh and located on the right bank of River Tigris (Dijla) [6, p. 328, 11]. Abd al-Rahman I built 'Al-Rusafa' Palace in honour of his grandfather's palace that holds the same name in the Levant [7, p. 53]. In conclusion, 
palaces in Levant and Andalusia were similar in the way they were named: whether after the owner's name, one of his relatives, the palace location or its design.

\subsection{Location selection}

Location selection was one of the most important things that caliphs took great care of when building their palaces; they made sure that the palaces were away from cities and the public and also had a beautiful view (top of hills) [6, pp. 303-304] (Fig. 1). They also liked to build their palaces on the banks of rivers and streams in order to enjoy the beauty of the river and the sound of its flow. This was also to provide a continuous uninterrupted water source in case of siege or wars [6, p. 328, 11, p. 328].

In times of war, caliphs tended to build their palaces inside forts [7, p. 114] or at mountain tops surrounded by deep grooves full of water [2, p. 330] to protect themselves, as in the case of Andalusia palaces which were built in the era of clashes between Muslim kings and the Christian kings.

\subsection{Space}

The palaces in Iraq and Andalusia were huge, and their gardens were very vast, which led to poets singing their praises. The biggest palace in Iraq was Al-Mahozh Palace, reaching a length of $1,100 \mathrm{~m}$ and a width of $250 \mathrm{~m}$ [6, p. 321]. Another example is Al-Heer Palace, which is surrounded by a fence that is $165 \mathrm{~m}$ long and about $152 \mathrm{~m}$ wide [5, p. 252, 6, p. 323].

In Andalusia, 'Al-Zahra' ' Palace is considered as one of the biggest palaces; its length is $1,300 \mathrm{~m}$ and its width is $800 \mathrm{~m}$. It is said that this palace had 15,000 doors armoured with copper and iron $[12,13]$. By the same token, many historians mention that Alhambra Palace can accommodate 40,000 men [1, p. 441].

\subsection{Cost}

It is natural that economic prosperity of nations has a direct effect on palace buildings. Palaces were manifestations of luxury and pleasure, as the caliphs paid enormous amounts of money for them. For example, 'Al-Zahra' ' Palace in Andalusia cost 300,000 dinar annually, and its construction lasted for almost 20 years [8, pp. 182-183, 14].

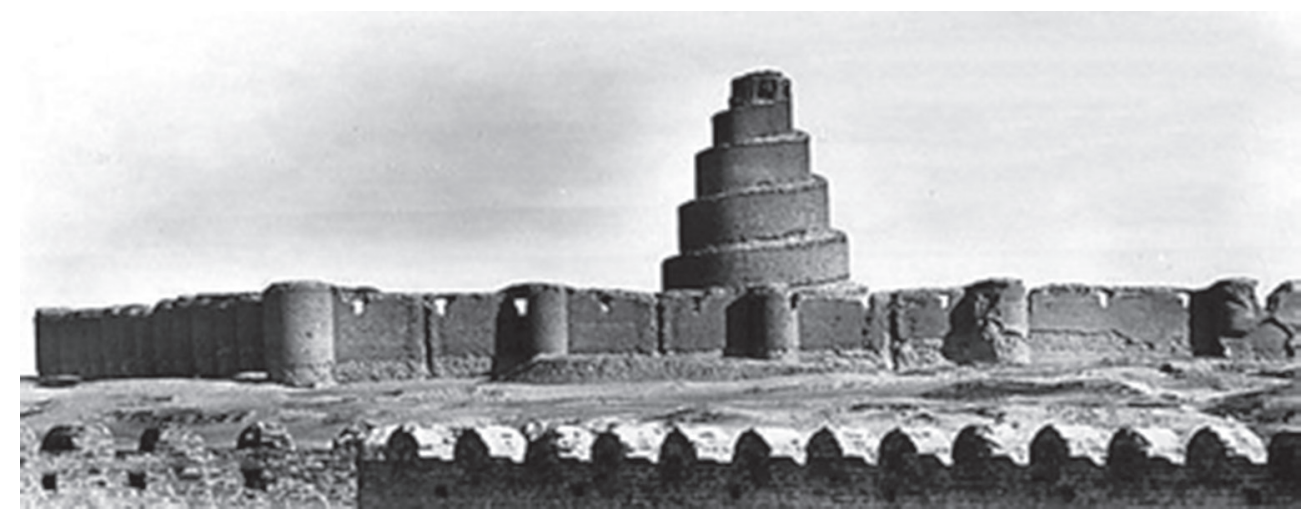

Figure 1: One of the Iraqi palaces built by al-Mutawakkil in Samarra. 
The cost was high not just because of the huge spaces required for a palace, but also because the materials used were expensive; there were antiques and gold-plated decorations. The caliphs took great care to avoid duplication of the palaces [8, p. 183, 14, p. 263]. For instance, 'Al-Zahra', Palace has many examples of unique and brilliant artwork. It has a statue of a beautiful lion, with diamonds in its eyes that reflect light on the lake of Waterwheel Palace [15] as well as a bathtub with statues of different animals and birds that are all made of red gold interspersed with precious pearls and luxurious diamonds [16] (Fig. 2).

Andalusia palaces are famous for its coloured glass with pictures of plants, animals, planets plus geometric forms. This glass was surrounded by frames made of pure gold [7, pp. 60-61]. Moreover, the floors were covered with brickwork inlaid with different types of pearls that were coordinated beautifully [7, p. 57].

The palaces of Andalusia exceeded their Iraqi counterparts in the use of gold and precious stones for decorations. It is to be noted that the construction of the palaces and the enormous amount of money paid for them were not very much linked to the economic situation of the state; there are some palaces that cost an excessive amount of money in spite of the harsh economic conditions at the time of building. Some luxurious palaces were built even during times of war with neighbouring countries, but this does not deny that there are some palaces in Iraq and Andalusia that reflect the economic and financial life of the state. In these palaces, cheap building materials were used instead of expensive frills, such as pebbles instead of mosaic and pearls [7, p. 67]. It seems that the economic conditions and political stability affected the building of palaces in Andalusia in terms of size, beauty and grandeur. However, in Iraq this was not the case; the caliphs were not affected by economics. They wanted to show off whatever their conditions were.

\subsection{Building schemes}

Palaces of Iraq and Andalusia have a lot in common; for example, the two were built at high sites, and if not, they had very high masonry fences. However, there are also many differences between them: palaces of Andalusia were characterized with no holes in their walls besides

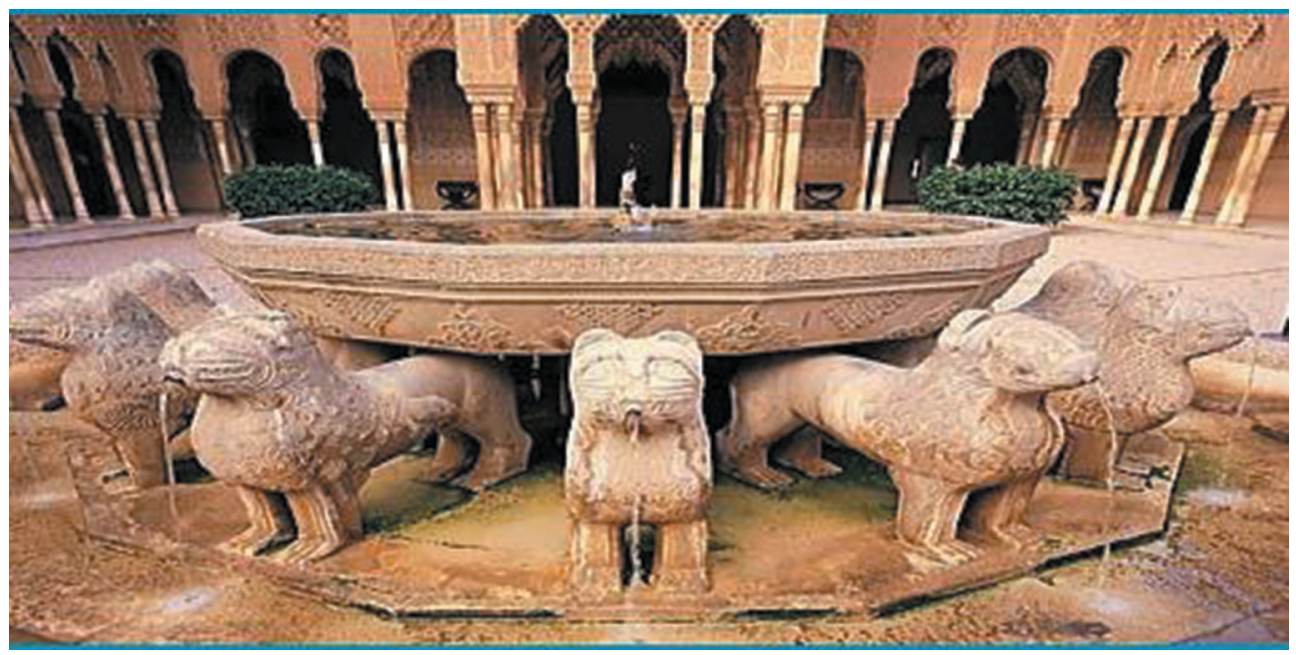

Figure 2: Example of statues of animals' fountain in Andalusia. 
having many towers. Al-Hamra Palace had 1,300 impenetrable towers [1, p. 441]. Many palaces were built to act as a fortress to live in at war times, thus they had deep trenches around them, such as Al-Oleiq Palace in Iraq which had a wide circular trench around it. Caliph al-Mutawakkil built a great wall wrapping the outside of the trench that measured $450 \mathrm{~m}$ in diameter and $20 \mathrm{~m}$ in height [6, p. 304].

Similarly, Al-Heer Palace had a rectangular yard, fenced with bricks (Fig. 3). The space of the palace was about $620,000 \mathrm{~m}^{2}$, as it stretches $650 \mathrm{~m}$ along the river 'Al-Qa'em', and is about $950 \mathrm{~m}$ wide [6, p. 325].

In addition, caliphs in Iraq and Andalusia were keen to provide a continuous water supply inside their palaces, whether by digging rivers [17, 18], as in 'Pearl Palace' in Iraq, or transferring water from rivers into the palaces through marble pipes, as in Al-Hamra Palace. Granada city was supplied with water from this palace; not only water for drinking but also for pools, fountains and public baths [19]. Water was an essential element to ensure that the palace will withstand the enemy and stay strong as long as possible. Moreover, water was also used for watering gardens [20] and supplying the huge pools in the palaces. One pool could occupy an area of 40,000 $\mathrm{m}^{2}$, like the pools of Al-Heer Palace in Iraq [6, p. 323]. Also, Al Jawasaq Palace had a pool that was $15 \mathrm{~m}$ long and $10 \mathrm{~m}$ wide [5, p. 237, 6, p. 306].

Caliphs not only built pools inside the palaces, but also decorated them perfectly. For instance, some pools such as the Al-Jawasaq Palace in Iraq were covered from the inside with gold [18, p. 406], silver or pure lead, which is more beautiful than silver [5, p. 237, 6, p. 306]. Beside the pools, the caliphs arranged expensive furniture. Some caliphs also decorated awesome trees made of gold with gems and pearls, and on the branches they had sculptures of birds that sang differently when air came out of them [5, pp. 244-245, 6, pp. 296-267]. Together, they created lovely music.

There were palaces that shared water sources, like Al-Maleeh and Al-Subaih Palaces, which were built next to each other with a stream between them. The stream poured into a pool made of green marble. Unlike the palaces of Iraq, the two had ostrich statues that spin in a water wheel [5, pp. 255-256, 6, p. 299].

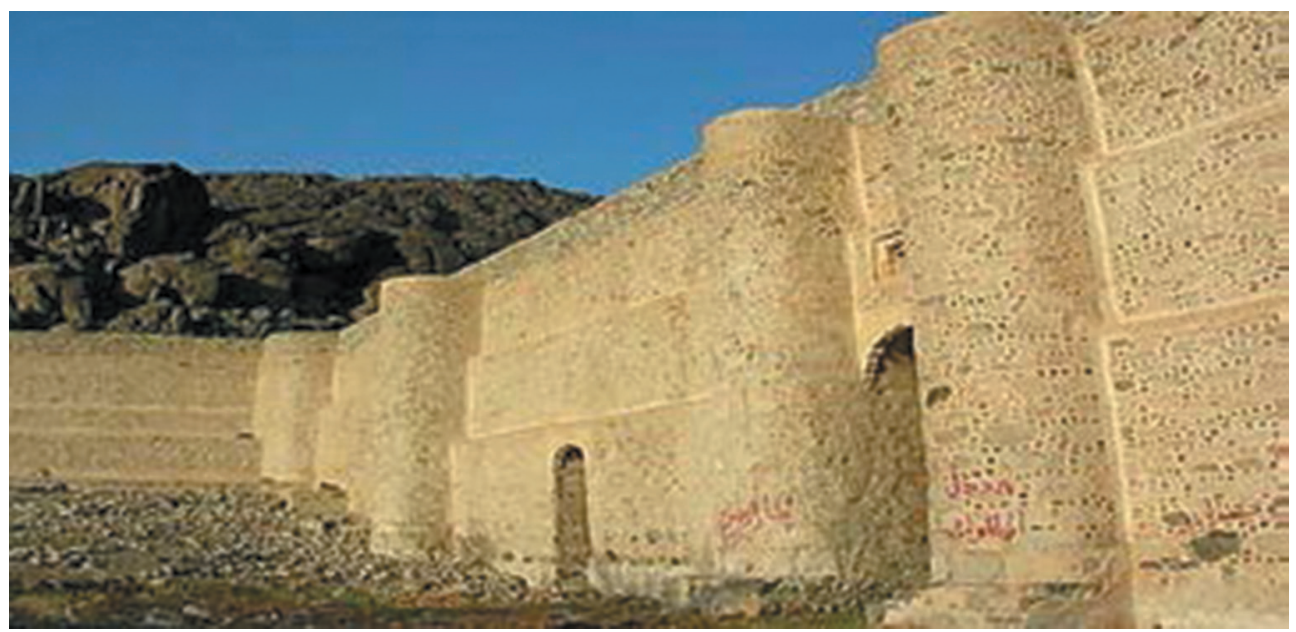

Figure 3: Example of Iraq palace fences made of bricks. 


\subsection{Division of palaces}

Palaces of Andalusia and Iraq were characterized with many rooms and halls that were used for public and private meetings [4, p. 107, 6, p. 318]. In general, rooms in the palaces were divided into four groups, each with eight rooms [6, p. 319] that were furnished with the most expensive furniture. Because of the large number of rooms, some of them were non-furnished [6, p. 331, 21] as for example in Al-Jaafari Palace. Palaces such as Al-Jawasaq Palace had special rooms for women. In addition, there were many front halls with a large inner courtyard, followed by many rooms that led to the throne hall [21, pp. 148-157]. Furthermore, palaces had courtyards, lobbies, official reception halls, mosques, special residence for special retinues, as well as military barracks for guards and the army [1, pp. 437-435, 22].

\subsection{Building styles}

In Iraq, many caliphs tried to imitate other kings when building their palaces, such as the Abbasi Caliph 'al-Mutawakkil' imitating the palaces of the Al-Heera kings in building his 'Balehir' Palace. The style was very unique; the palace was built in the model of a war formation to remember wars at all times. The front part was for the king, whereas the right side and the left side were for the retinue. Behind the right side there were clothes cabinets, and behind the left side there was the drink [23]. Palaces of Andalusia had two styles: the first one is building the palace around a circular yard. This style was taken from Umayyad palaces in the Levant. The second was taken from the palaces of the Abbasids in Iraq, which was originally copied from Persian palaces. Here the palaces were designed in the form of parallel long rooms separated by columns [7, p. 57].

In the beginning, Andalusian palaces were influenced by Arab culture, with Arabic ornaments and verses from the Quran [7, p. 69]. As time passed, this influence became weaker and weaker; marble pillars topped with crowns of alabaster were used [7, p. 67]. Moreover, they used beautiful patterns of art from Byzantines in which they drilled marble columns, stone paintings and the crowns [7, p. 58].

\subsection{Ornament pattern}

Initially, Islamic arts and paintings did not use animal or human paintings, on the grounds that some scholars had prohibited this kind of drawings. Muslims drew plants and geometric shapes and wrote Arabic poems, verses from Quran, and proverbs to decorate the domes of palaces [21, pp. 148-150]. On the floors, they used mosaics, gold, and stained glass [4, p. 106, 22, p. 186].

In Iraq, Abbasid palaces had many paintings depicting animals, birds, and even humans. Historians say that 'Al-Mukhtar' Palace in Iraq had a mural that referred to the allegiance of monks, known as 'Shahar Al-bai'a' [18, p. 406, 24].

On the contrary, palaces of Andalusia exaggerated in drawings of humans and animals, to the extent of even making gold-covered animal and bird statues [7, p. 100]. Besides this, Muslims in Andalusia wrote verses from Quran, Hadiths (Prophet Mohammad's sayings), poems [25] and proverbs that symbolized strength and empowerment [26, 27]. They also drew geometric shapes representing stars, planets and many different flowers and fruits [7, p. 104, 28]. In the era of Unitarians, palaces of Andalusia were characterized by complex, nested and overused ornaments [27, p. 64] (Fig. 4). 


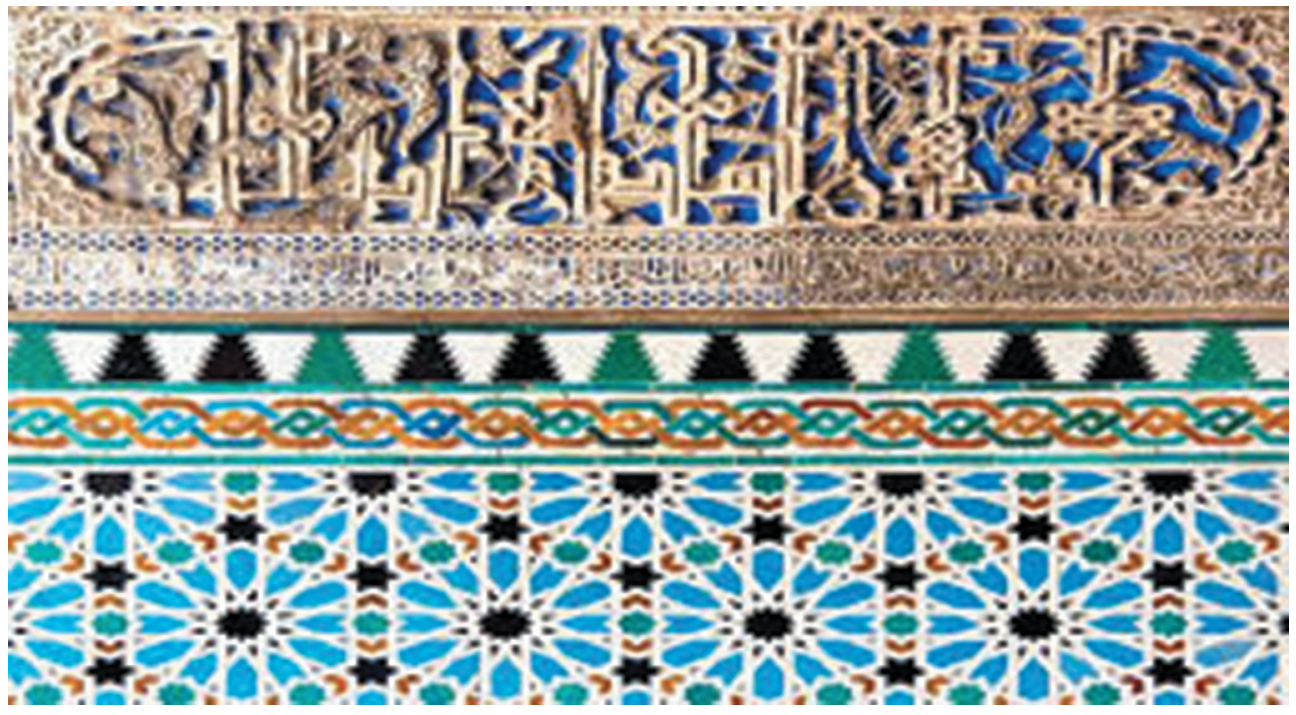

Figure 4: Example of Andalusia palaces decorated with verses from the Quran on the top and geometric shapes below.

Caliphs liked installing animal statues at the entrances of palaces, around pools and around interior yards [27, p. 201, 28, p. 200]. Sometimes, they placed them inside their rooms, as in 'Al-Burj Palace' (The tower) in Iraq, where the caliph decorated an enormous bed with statues of eagles and lions [18, p. 406]. Palaces in Andalusia had diverse collections of statues; for example, Al-Zahra' Palace had a pool surrounded by a dozen statues with water coming out of their mouths. There were a lion, deer, crocodile, snake, falcon, elephant, dove, Shaheen bird, peacock, chicken, rooster and eagle [29].

\subsection{Materials used}

Caliphs in Iraq and Andalusia took pride in their palaces, so they put a great deal of effort to make them gorgeous and unique. They tried to distinguish their palaces from the palaces of

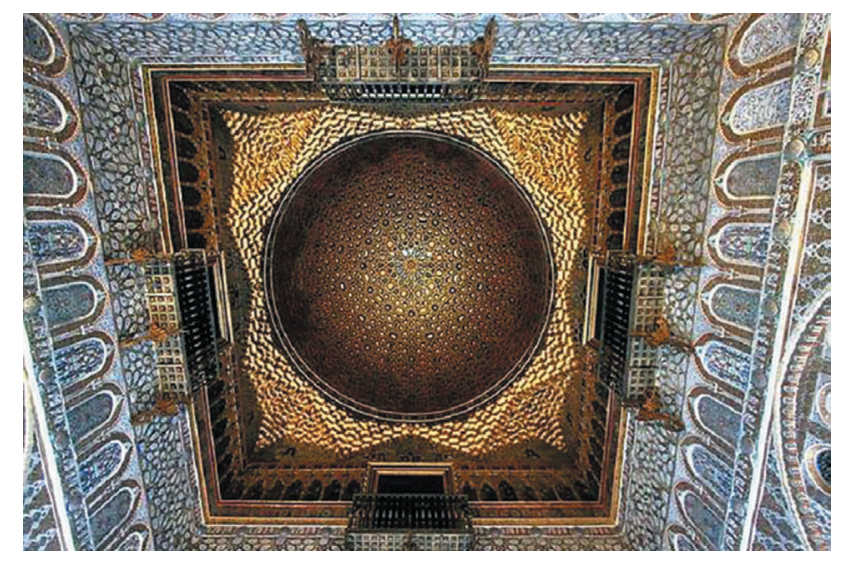

Figure 5: Example of a decorated ceiling in one of Palaces in Andalusia 
rich people; consequently, they decorated the floors creatively by drawing floral ornaments inlaid with gold and coloured glass [4, p. 106, 22, p. 186]. The ceilings were decorated with tiles coated with gold [7, p. 54] (Fig. 5). The walls were decorated with frescoes, mirrors, colourful seashells, water paintings and silver pieces coated with gold. Columns were made of alabaster and marble [5, pp. 237-255, 7, p. 54, 30].

With the passage of time, caliphs decorated their palaces luxuriously; they dressed the walls with gold, marble and mosaics from inside and outside [7, p. 54, 18, p. 406]. Moreover, the statues were made of gold, such as the two deer that were found in 'Al-Mu'tamed' Palace [7, p. 100].

In addition, caliphs excelled in decorating the pools despite its large size and the luxurious furniture placed around the pools were coated with gold and silver [18, p. 406]. The statues around the pools were also made of pure silver, coated with gold, or even adorned with gems and pearls [7, p. 110]. Many palaces had domes that were decorated with drawings of stars and planets. Some domes had small windows from which light enters to be reflected beautifully on the walls of the lobby [7, p. 103].

Some caliphs used tubes of white marble for piped supply of water from the pools to their bathrooms [5, pp. 237-255, 30]. The doors of the palaces were fine masterpieces made of deluxe wood and decorated with copper and gold. The windows were usually adorned with coloured glass [4, p. 108, 22, p. 186]. Some palaces were painted with fantastic colours such as 'Al-Gard' Palace in Iraq, which was painted bright white by Caliph al-Mutawakkil.

\section{RESULTS}

1. Palaces in Iraq and Andalusia were characterized by simplicity in outer shape and artistic beauty within.

2. These palaces represent the development in building from simple palaces built on small spaces to large ones that cost millions.

3. Caliphs were keen to allocate a place for praying in their palaces.

4. Flow of water was one of the most important priorities of the caliphs to be a part of their palaces.

5. Caliphs were keen to build luxurious palaces and decorate them with expensive materials.

6. Despite the luxury inside, the majority of palaces in Iraq and the Levant were built as defensive citadels.

7. The palaces were influenced by neighbouring civilizations; however, the designs were modified to suit Islamic cultures.

8. Palaces in Iraq and Andalusia often reflect the status of luxury and well-being of the state.

9. Palaces in Iraq and Andalusia were similar in construction, selection of sites and fortification.

10. Palaces in Iraq were influenced by Persian style, whereas palaces in Andalusia were influenced by Persian, Byzantine and Shami (Levant) styles.

11. Palaces in Iraq were not affected by the economic situation in the country, which was not the case in Andalusia.

12. The overall design of palaces in Andalusia and Iraq combines the authenticity of Islamic culture and their neighbourhood nation's civilizations. 


\section{REFERENCES}

[1] Annan, Mohammed Abdullah, Islamic State in Andalusia, Vol. 5, 4th ed., Khanji Library: Cairo, Egypt, p. 508, 1997.

[2] Durant, William \& Durant, James, The Story of Civilization, Vol. 13, Trans. Zaki Naguib Mahmoud et al., ed. Mohiuddin Saber, Arab League of Educational Cultural and Scientific Organization: Tunisia, p. 239, 1988.

[3] Ibn Khaldun \& Abdul Rahman bin Mohammed bin Mohammed, Ibn Khaldun Journey, Vol. 4, 1st ed., ed. Mohammed bin Tawit Tunji, Dar Al-Kotob Al-ilmiyah: Lebanon, p. 144, 2004.

[4] Al-Samarrai, Ibrahim Younis, The History of Samarra, Dar Albasry, Iraq, 1st ed., p. 130, 1971.

[5] Al-Samarrai, Younis Ahmed, Samarra in the Literature of the Third Century AH, Irshad Press: Iraq, p. 244, 1968.

[6] Al-Sharqi, Taleb Ali, Arab and Islamic Iraqi Palaces until the End of the Abbasid Era: 656 AH, 1st ed., Dar Public Cultural Affairs: Baghdad, Iraq, p. 309, 2001.

[7] Salem, Abdulaziz et al., Mosques and Palaces in Andalusia, University Youth Foundation: Alexandria, Egypt, p. 111, 1986.

[8] Al-Samarrai, Khalil et al., Arab History and Civilization in Andalusia, 1st ed., The United New Book Press: Beirut, Lebanon, p. 182, 2000.

[9] Al-Ali, Saleh Ahmed, Baghdad Administrative and Constructional Landmarks: Planning Study, Cultural Affairs Press: Iraq, p. 21, 1988.

[10] Al-Hamwi, Yacout, Lexicon Countries, Vol. 3, ed. Fareed Al-Jundi, Scientific Books Press: Beirut, p. 197, 1990.

[11] Tabari, Mohammad bin Jareer, The History of Nations and Kings, Vol. 5, Dar Al-Ma'ref: Egypt, p. 328, 1967.

[12] Al-Dhahabi, Shams al-Din Abu-Abdullah Muhammad bin Ahmad, The History of Islam and the Deaths of Celebrities and Figures, Vol. 25, Dar Alkitab Alarabi: Lebanon, p. 247, 1987.

[13] Al-Samarrai, Younis Ahmed, History of Arab and Their Civilisations in Andalusia, Dar Alketab Aljaded, Libya, p. 183, 2000.

[14] Ibn Emad Al-Hanbali \& Abdul-Hai bin Ahmed bin Mohammed Abu Falah, Shatharat Al-dhahab fi Akhbar mn Dhahad (Gold Nuggets in the News of who Passed), Vol. 4, 1st ed., ed. Mahmoud Arnaout, Dar Ibn Katheer: Damascus, Syria, p. 263, 1985.

[15] Al-Mokri, Shahabuddin Ahmed bin Mohammed, Flowers of Gardens in the News of Judge Ayyad, Vol. 2, ed. Mustafa Sakka et al., Committee of Authoring, Translation and Publishing Press: Cairo, Egypt, p. 266, 1939.

[16] Al-Mokri, Shahabuddin Ahmed bin Mohammed, Nafh Alteeb mn Ghosn Al-Andalus Alrtaib (The Perfume Blowing of Andalusia Wet Branch), Vol. 1, ed. Ihsan Abbas, Dar Sadr: Beirut, Lebanon, p. 264, 1900.

[17] Ibn al-Athir, Abu Hassan Ali bin Abi Karam, The Perfect in History, Vol. 4, 4th ed., ed. Alturath Library, Encyclopaedia of Arab History: Beirut, Lebanon, p. 338, 1993.

[18] Noueiri, Ahmed bin Abdul Wahab bin Mohammed, The End of the Need in the Arts of Literature, 1st ed., Dar ElKotob (National Library \& Archives of Egypt): Cairo, Egypt, p. 292, 2002.

[19] Al-Salabi, Ali Mohammed Mohammed, State of Unitarians, Dar Albayarek Publication: Amman, Jordan, p. 245, 1998.

[20] Ibn Khaldun, Abdul Rahman bin Mohammed bin Mohammed, Ibn Khaldun History, Vol. 3, Dar Alfeker: Amman, Jordan, p. 342, 2001. 
18 Islamic Heritage Architecture

[21] Herzfeld, Ernst, Excavations in Samarra: Ornaments of Buildings in Samarra and the Art of Decorating, Trans. Ali Yahya Mansour, The General Organization of Antiquities and Heritage: Baghdad, Iraq, pp. 151-157, 1985.

[22] Ghazi, Rajab Mohammad, Arabic Architecture in the Islamic Era in Iraq, the Faculty of Arts, University of Baghdad: Baghdad, p. 186, 1989.

[23] Masoudi, Abu al-Hasan bin Ali, Gold Fields and the Metals of Gems, Vol. 4, ed. Kamal Hassan Marei, Modern Library: Sidon, Lebanon, p. 72, 2008.

[24] Al-Yacoubi, Abu Abbas Ahmad bin Ishaq bin Jaafar, Lexicon Countries, Vol. 5, Dar Sader Publishers: Beirut, Lebanon, p. 70, 1988.

[25] Ibn Zamrak, Mohammed Ben Youssef Al-Andalusi, The Diwan of ibn Zamrak Al-Andalusi, 1st ed., ed. Mohamed Tawfiq Ennifar, Dar Al-Gharb Al-Islami: Beirut, Lebanon, pp. 5-19, 1997.

[26] Tawfiq, Omar Ibrahim, The Political, Social and Cultural Image of the Andalusian Society in the Fifth Century, Dar Ghaida: Amman, Jordan, p. 135, 2010.

[27] Annan, Mohammed Abdullah, Remaining Relics of Andalusia in Spain and Portugal, Khanji Library: Cairo, Egypt, p. 194, 1961.

[28] Farhat, Yousef Shokri, Granada in the Shade of Bani Al-Ahmar, University Corporation for Publication: Beirut, Lebanon, p. 197, 1982.

[29] Salem, Assayed Abdul Aziz, The History of Muslims in Andalusia and Their Monuments: From the Arab Conquest until the Fall of the Caliphate in Cordoba, University Youth Foundation: Alexandria, Egypt, p. 408, 1997.

[30] Al-Sharqi, Taleb Ali, Iraq Palaces, Dar Alshuon Althaqafiah, Baghdad, Iraq, pp. 299_ $331,2001$. 